\title{
9 Finding Out More
}

There are at least three areas of interest associated with open learning which you might want to find out more about:

other Open BTEC courses

other open learning courses outside the Open BTEC scheme more detailed information on how to improve your study skills

To find out about other Open BTEC courses is easy. Your learning centre will be able to give you details of where to get this information.

Finding information about other open learning courses is a little more difficult. You could try, first of all, asking your course tutor. For courses at university level, write to:

The Associate Student Central Office

The Open University

P.O. Box 76

Milton Keynes

MK7 6AN

For a range of other courses you could try:

The National Extension College

18, Brooklands Avenue

Cambridge

CB2 2HN

or your Local Authority. Many local authorities are currently setting up open learning support schemes and, where this is the case, they will be able to provide you with information on the complete range of Open Tech courses.

Finally, if you want to work at 'honing up' your ability to study, including improving your reading, try reading:

a Learn How to Study, by Derek Rowntree, published by Macdonald \& Co (1976).

b any of the booklets in the series 'Study Skills', published by the National Extension College, and available from the address above.

C A Guide to Learning Independently by Lorraine Marshall and Frances Rowland, published by the Open University Press (1981). 